\title{
Feeling Better While Waiting: Hospital Lobby in Portugal and South Korea
}

\author{
Sandra Maria Correia Loureiro \\ Instituto Universitário de Lisboa (ISCTE-IUL) and Business Research Unit \\ (BRU/UNIDE) and SOCIUS
}

Eduardo Moraes Sarmento

Universidade Lusófona and ISEG/UTL

Rui Lopes

Universitário de Lisboa (ISCTE-IUL)

Ki Nam Jin

Yonsei University

\begin{abstract}
This study aims to explore the effect of three factors of Servicescape on customers' emotion, perceived quality and image. The proposed model was tested in medical tourism context in Portugal and S. Korea, using a sample of 359fully completed questionnaires. Findings reveal that ambient and design are the most important factors in formation Servicescape itself in the case of Portugal hospitals and design and social factors in the case of S. Korea hospitals. Servicescape is an effective antecedent of customer image, perceived quality and pleasure-feeling. Finally, the article also provides managerial implications and suggests avenues for further research.
\end{abstract}

Keywords: ambient factor, design factor, social factor, perceived quality, pleasurefeeling, medical tourism

\section{Introduction}

Medical tourism is a growing phenomenon in Asia and also in European countries, where patients are willing to travel for the purposes of receiving medical care and surgical treatments (Lee et al., 2002; Smith and Puczkó, 2008; Lunt et al., 2011).An ageing population, older people's requirements for more medical services, people wanting to look and feel younger, and waiting times and/or the increasing cost of health services at home, has lead new healthcare consumers to seek treatment abroad (Hazarika, 2010).

In this vein, understand how customers view the lobby Servicescape and how that customer perception can influence the evaluation of service quality, the perceived 
image and the pleasure-feeling becomes an interesting topic not yet properly explored in medical tourism context. Hospitals dedicated to medical tourism located in two cities (Lisbon and Seoul) were selected to test the model. Portugal (in Europe) and South Korea (in Asia) are two countries where medical tourism are emerging and are doing an effort in providing high standard of facilities, equipment and staff and medical teams with advanced knowledge and skills (medical tourism magazine, 2014; medical tourism magazine- Jeju, 2014).

Therefore, after the introduction, a contextualization of medical tourism in the health tourism context, the theoretical background, the proposed model and hypotheses are presented and discussed. Then, the methodology, data collection, and results are described. Finally, the article presents conclusions, managerial implications, and future research.

\section{Medical Tourism in the Health Tourism Context}

The globalization of health care is responsible for the phenomenon of medical tourism, where citizens decide to have their own treatment abroad and travel often to less economically developed areas of the world (Ehrbeck et al., 2008). Carrera and Bridges (2006, p. 447) define medical tourism as a subset of health tourism, whose broader definition involves "the organized travel outside one's local environment for the maintenance, enhancement or restoration of the individual's wellbeing in mind and body". The globalization and increasing acceptance of health services as a market commodity have led to a new trend; organized medical tourism for fee paying patients, regardless of citizenship, who shop for health services overseas using new information sources, new agents to connect them to providers, and inexpensive air travel to reach destination medical (Whittaker, 2010; Crooks et al., 2010).Medical tourism integrates a heterogeneous collection of health-related travel (Goodrich, 1993; Huat, 2006a, 2006b; Fedorovet al.,2009) and spans a wide range of medical specialties, such as cosmetic surgery, dental procedures, orthopaedic surgery, cardiac surgery, assisted reproductive technology and organ and cellular transplantation.

Recent studies within tourism research has started to explore the intersection between health and tourism (e.g., Lee, 2010; Hall, 2011; Heung et al., 2010).Other studies for patient mobility include the desire to avoid long waiting times for certain procedures and to avoid restrictive eligibility rules for particular treatments and services. The growing ease and affordability of international air travel and the expansion of internet marketing are also factors influencing the decision of citizens to seek treatment abroad (Lunt et al., 2010; Crooks et al., 2010). Some patients are also likely to be attracted by the privacy and confidentiality afforded by distant destinations. Others may be attracted by the availability of a wider variety of holistic alternatives and complementary approaches to medicine and wellness services provided in some countries (Gesler, 1992).

Medical tourism generates income for the health sector of the destination country whilst increasing tourist spend on air fares, accommodation, subsistence and excursions is also an important source of foreign exchange income for destination countries (Johnson and Garman, 2010). A substantial level of expenditure by medical tourists, and their companions, is not related to medical care. For example, it is estimated that those accompanying the patient can spend about twice as much on hotels and tourism activities as the patient (NaRanong and NaRanong, 2011). 
In Portugal, the official services for the provision of health care to the population are organized under the National Health Service. In addition to the public service, there are private hospitals and offices of professionals in the liberal regime. The hospital network consists of modern, well-equipped units, distributed across the country and there is much work with leading international insurers. In order to best accommodate the patient abroad, hospitals have been implementing and monitoring care services customized to the patient, being English the basic language of communication. Portugal also has an Integrated Medical Emergency, which provides victims of accidents or sudden illness, prompt and accurate delivery of health care, with high levels of speed in drive assistance means. The World Health Report, evaluated the Portuguese health system in the 12th position in the ranking of the World Health Organization (WHO, 2014).

In South Korea, according to the Ministry of Health and Welfare, 210,000 nonKorean patients from 191 nations received medical treatment in Korea in 2013. This is an increase of $32.5 \%$ from the 159,464 in 2012, and is a 3.5 -fold increase over 2009's figures. By nationality, 57,075 Chinese patients were treated in South Korea in 2013, followed by 32,750 Americans, 24,026 Russians, 16,849 Japanese and 12,034 Mongolians. Most of all, the number of inbound Russian patients increased by nearly $46 \%$ in 2013 over the previous year (IMTJ, 2014).

The type of treatments most commonly sought by medical travellers to South Korea is internal medicine procedures, including problems with the digestion and circulatory systems. They accounted for 68,453 patients, making up 24.4 percent of last year's medical tourists. Some 28,135 patients, or $10 \%$, came for general health check-ups, while $25,101 \%$, or $9 \%$, had dermatological treatments for skin problems. A total of 24,075 patients, $8.6 \%$, sought cosmetic surgery, while 15,899 patients, or $5.7 \%$, used Seoul's gynaecological services (medical tourism magazine- Jeju, 2014).

\section{Theoretical Background}

The current study based on the S-O-R framework to propose a model linking Servicescape to pleasure-feeling, service quality and image. The S-O-R framework is firstly presented in the context of environmental psychology by Mehrabian and Russel (1974) and first applied on retail context by Donovan and Rossiter (1982). These authors investigate the relationship between emotional states, induced by several different environments, and their behavioural intentions. In this application, the stimuli were operationalized as components of the atmosphere, the organism as consumers' emotional states (such as pleasure and arousal) and the response as attitudes and behavioural intentions (approach and avoidance) (Donovan and Rossiter, 1982).Thus, an adequate S-O-R framework should regard three elements: taxonomy of stimulus, organism and taxonomy of responses (Donovan and Rossiter, 1982).This model also suggests that the stimuli precede and affect the consumers' emotional states (organism), which influence their retail behaviours (responses) such as repatronage, store search and in-store behaviour (Thangand Tan, 2003).

The stimulus is a set of characteristics inside the environment which affect the internal states of the individuals (e.g., Baker, Levy and Grewal, 1992; Eroglu, Machleit and Davis, 2001; McKinney, 2004; Sherman, Mathur and Smith, 1997). Organism refers to the intervening internal process, which take place between the stimulus and the final actions, causing alterations on the emotional states of the 
consumer. That process allows the consumers to convert the stimulus into meaningful information and utilize them to understand the environment before making a decision (Koo and $\mathrm{Ju}, 2010$ ). The response is used to express the satisfaction or disatisfaction with the consumer experience (McKinney, 2004) and according to Donovan and Rossiter (1982) that can be trough approach and avoidance behaviours.

\section{Servicescape}

This study employs ambient factor, design factor and social factor as stimulus, also called Servicescape (Bitner, 1992), pleasure-feeling as positive emotions and perceived service quality and image as response. In fact, as Bitner (1992) points out the place where the service is produced cannot be hidden and may have a strong effect on customers' perceptions of the service experience. Booms and Bitner (1981, p. 36) define Servicescape as "the environment in which the service is assembled and in which seller and consumer interact, combined with tangible commodities that facilitate performance or communication of the service". Bitner (1992) suggests three dimensions of the physical environment: (i) ambient conditions (e.g. temperature, air quality, noise, music, and odour),(ii) spatial layout and functionality (e.g. layout, equipment, furnishings) and (iii) signs, symbols and artefacts (e.g. signage, personal artefacts, style of décor).

Wakefield and Blodgett (1994) analyse the effect of the Servicescape in leisure service settings and propose a Servicescape typology in terms of:(i) spatial layout and functionality (e.g., stadium seats, ticket windows/gates, hallways/walkways, entrances/exits, food service areas, and restrooms) and (ii) aesthetics (e.g., external environment, exterior construction, interior construction, score boards, facility cleanliness, and personnel appearance). Lucas (2003) identifies five main factors of Servicescape in the slot floor of the hotel casino: (i) layout navigation (ii) cleanliness, (iii) ambience, (iv) seating comfort and (v) interior décor. Ryu and Jang (2007) and Kim and Moon (2009) employ five composite dimensions for restaurant context: (i) facility aesthetics, (ii) layout, (iii) electric equipment, (iv) seating comfort, and (v) ambient conditions.

Therefore, the factors that comprise the Servicescape depend on the context. For the purpose of this study, three factors are considered: (i) ambient factor regarding background characteristics of the environment (e.g., odour, lighting, temperature, music/sound, noise level and cleaning); (ii) design factor referring the way in which equipment and furnishings are organized and colour schema (e.g., electronic equipment, layout, signage, restroom, wall and floor colour schemes, architectures and pictures); (iii) social factor (e.g., number, characteristic and empathy of employees).

\section{Consequences of Servicescape stimuli and hypotheses development}

Pleasure-feeling has been regarded as a direct consequence of Servicescape, especially in more hedonic services (e.g., Kim and Moon, 2009; Ryu and Jang, 2007; Wakefield and Blodgett, 1994; Loureiro, Koo and Lara, 2013). In fact, pleasurefeeling defined as an overall sensation of happiness, delighted and entertained may be more effective in case of ambient, design and social associated to the lobby of an health care hedonic service, where feeling pleasure can result in trust and hope in 
treatment to be carry out, then in a less hedonic environments. This leads us to propose (see Figure 1):

H1: Perceptions of the lobby Servicescape have a positive effect on pleasurefeeling.

Service quality, viewed as a cognitive overall judgment on the perception of the product on the quality attributes is another consequent of Servicespace (Bitner, 1992; Turley and Fugate, 1992; Wakefield and Blodgett, 1999; Hightower, Brady, and Baker, 2002). Thereby, the environment factors of the health care lobby should have an effect on customers' perception of service quality and so the following hypothesize is proposed:

H2: Perceptions of the lobby Servicescape have a positive effect on perceived service quality.

A cognitive appraisal of a situation or product can leads to an emotions (Lazarus, 1991). Thus, a favourable perception of service quality can enhance the level of emotion such as pleasure-feeling (e.g.,Wakefield and Blodgett, 1999).Therefore, a favourable quality perception of the ambient, design and social factors of the lobby is expected to raise the level of pleasure-feeling and so the following hypothesis is proposed:

H3: Customers' perceived lobby service quality has a positive effect on the level of pleasure-feeling experienced by them.

A well-presented physical and social environment may be very influential in communicating the firm's identity which become in customer's image (Bitner, 1992; Rapoport, 1982). Defining image as the consumer's mental representation of the firm or "the overall perception or total set of impressions of a place, or even as the mental portrayal of a destination" (Loureiro and Miranda, 2008, p.120), a lobby Servicescape may influence positively or negatively such impression or mental representation of the health care hospital. Thus:

H4: Perceptions of the lobby Servicescape have a positive effect on customers' image.

As demonstrated previously, customer overall image about a place or lodging can enhance the service quality evaluation (e.g., Gröonros, 1990; Loureiro and Miranda, 2008). So, it is expected that a good impression in customers' mind about the lobby may influence positively the evaluation of the service quality, therefore:

H5: Image of the lobby has a positive influence on quality perceived by customers. 
Figure 1: Proposed model

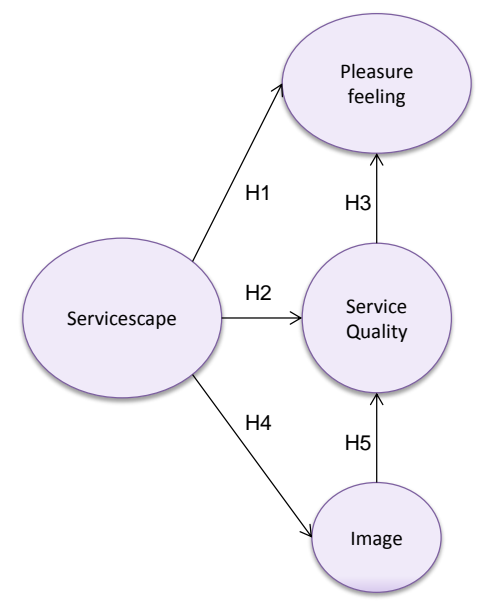

\section{Methodology}

\section{Data collection}

First the questionnaire containing the items of the constructs and the sociodemographic variables was written in English, then translated to Portuguese, and translated back to English. Back translation was used to ensure that the items in Portuguese communicate similar information as those in English (Brislin, 1970). Then, the questionnaire was pre-tested with the help of ten customers. The same procedure was employed for Korean questionnaire (translation and back translation). In S. Korean the questionnaire was pre-tested with the help of ten customers.

Data was collected during the period of September to October of the year 2013 (in main medical private hospitals in Lisbon and Seoul). We collected 166fully completed questionnaires from 200 distributed in Lisbon and 193 fully completed questionnaires from 200 distributed in Seoul (see Table1).

Table 1: Respondents Profile.

\begin{tabular}{ccc}
\hline & \multicolumn{2}{c}{ Respondents in Portuguese hospitals } \\
\hline Gender & Age & Qualifications \\
\hline Male $: 40.5 \%$ & $<20: 11.4 \%$ & Primary school: $3.3 \%$ \\
Female: $59.5 \%$ & 21 to $30: 35,8 \%$ & Middle school: $7.8 \%$ \\
& 31 to $40: 18,4 \%$ & High school: $33.1 \%$ \\
& 41 to $50: 20,5 \%$ & Bachelor: $33.1 \%$ \\
& 51 to $60: 10,8 \%$ & Post-graduation (master, PhD or DBA): $22.6 \%$ \\
& $>60: 3,0 \%$ & \\
\hline Gender & Respondents in S. Korean hospitals \\
Male : $42.5 \%$ & Age & Qualifications \\
Female: $57.5 \%$ & 21 to $30: 19.2 \%$ & Primary school: $1.6 \%$ \\
& 31 to $40: 19.0 \%$ & Middle school: $1.0 \%$ \\
& 41 to $50: 27.5 \%$ & High school: $30.0 \%$ \\
& $>50: 21.2 \%$ & Bachelor: $56.0 \%$ \\
\end{tabular}




\section{Variable and Measurement}

The constructs were measured with multi-item scales. All items were measured by using a 5-Point Likert-type scale and the questionnaire was constructed with 28 items representing the constructs (see Table2).

Table 2: Construct, $\mathrm{n}^{\mathrm{o}}$ of items, and sources.

\begin{tabular}{c|ccc}
\hline \multicolumn{2}{c}{ Construct } & No. of items & Source \\
\hline \multirow{2}{*}{ Servicescape } & Ambient factor & 6 & $\begin{array}{c}\text { Michaelia(2008); Wakefield and } \\
\text { Blodgett (1994) }\end{array}$ \\
& Design factor & 5 & Hightower, Brady and Baker (2002) \\
\cline { 2 - 4 } & Social factor & 6 & Kim and Moon(2009) \\
\hline \multicolumn{2}{c}{ Pleasure Feeling } & 4 & Jeon (2011) \\
\hline
\end{tabular}

\section{Measurement Results}

We employ the PLS approach to test the model with second order formative construct, more specifically we use the repeated indicators method (Chin et al., 2003; Kleijnen et al., 2007). A PLS model should be analysed and interpreted in two stages. First, the measurement model or the adequacy of the measures is assessed by evaluating the reliability of the individual measures, the convergent validity, and the discriminant validity of the constructs.Then, the structural model is evaluated Chin et al., 2003; Kleijnen et al., 2007).

In order to evaluate the adequacy of the measures item reliability is assessed by examining the loadings of the measures on their corresponding construct. Item loadings of scales measuring reflective constructs should be 0.707 or more, which indicates that over $50 \%$ of the variance in the observed variable is explained by the construct (Wetzels, Odekerken-Schröder and van Oppen 2009). We analysed the item loading of each item of reflective indicators and all of them exceed the value of 0.707 , items with factor loading lower than 0.707 were eliminated (see Table 3 ).

Table 3: Measurement Results.

\begin{tabular}{|c|c|c|c|c|c|c|c|c|c|c|}
\hline \multicolumn{6}{|c|}{ Data from Portugal (Lisbon) } & \multicolumn{5}{|c|}{ Data from S. Korea (Seoul) } \\
\hline $\begin{array}{l}\text { Items and } \\
\text { constructs }\end{array}$ & $\begin{array}{c}\text { LV } \\
\text { Mean }\end{array}$ & $\begin{array}{c}\text { Factor } \\
\text { loading }\end{array}$ & AVE & $\begin{array}{c}\text { Cronbach } \\
\text { Alpha }\end{array}$ & $\begin{array}{l}\text { Composite } \\
\text { reliability }\end{array}$ & $\begin{array}{c}\text { LV } \\
\text { Mean }\end{array}$ & $\begin{array}{c}\text { Factor } \\
\text { loading }\end{array}$ & AVE & $\begin{array}{c}\text { Cronbach } \\
\text { Alpha }\end{array}$ & $\begin{array}{c}\text { Composite } \\
\text { reliability }\end{array}$ \\
\hline $\begin{array}{l}\text { Servicescap } \\
\text { e- Ambient } \\
\text { factor }\end{array}$ & 3.97 & & 0.553 & 0.838 & 0.881 & 3.77 & & 0.550 & 0.729 & 0.830 \\
\hline $\begin{array}{l}\text { The odour } \\
\text { in the lobby } \\
\text { is pleasant }\end{array}$ & & 0.718 & & & & & 0.757 & & & \\
\hline $\begin{array}{l}\text { The lighting } \\
\text { in the lobby } \\
\text { is adequate }\end{array}$ & & 0.741 & & & & & 0.716 & & & \\
\hline $\begin{array}{l}\text { Overall, the } \\
\text { lobby is } \\
\text { kept clean }\end{array}$ & & 0,764 & & & & & 0,764 & & & \\
\hline $\begin{array}{l}\text { The } \\
\text { temperature } \\
\text { in the lobby } \\
\text { is } \\
\text { comfortable }\end{array}$ & & 0.778 & & & & & 0.788 & & & \\
\hline
\end{tabular}


Table 3: Measurement Results (cont'd)

The

background

music/soun

$\mathrm{d}$ is

appropriate

The noise

level in the

lobby is

acceptable

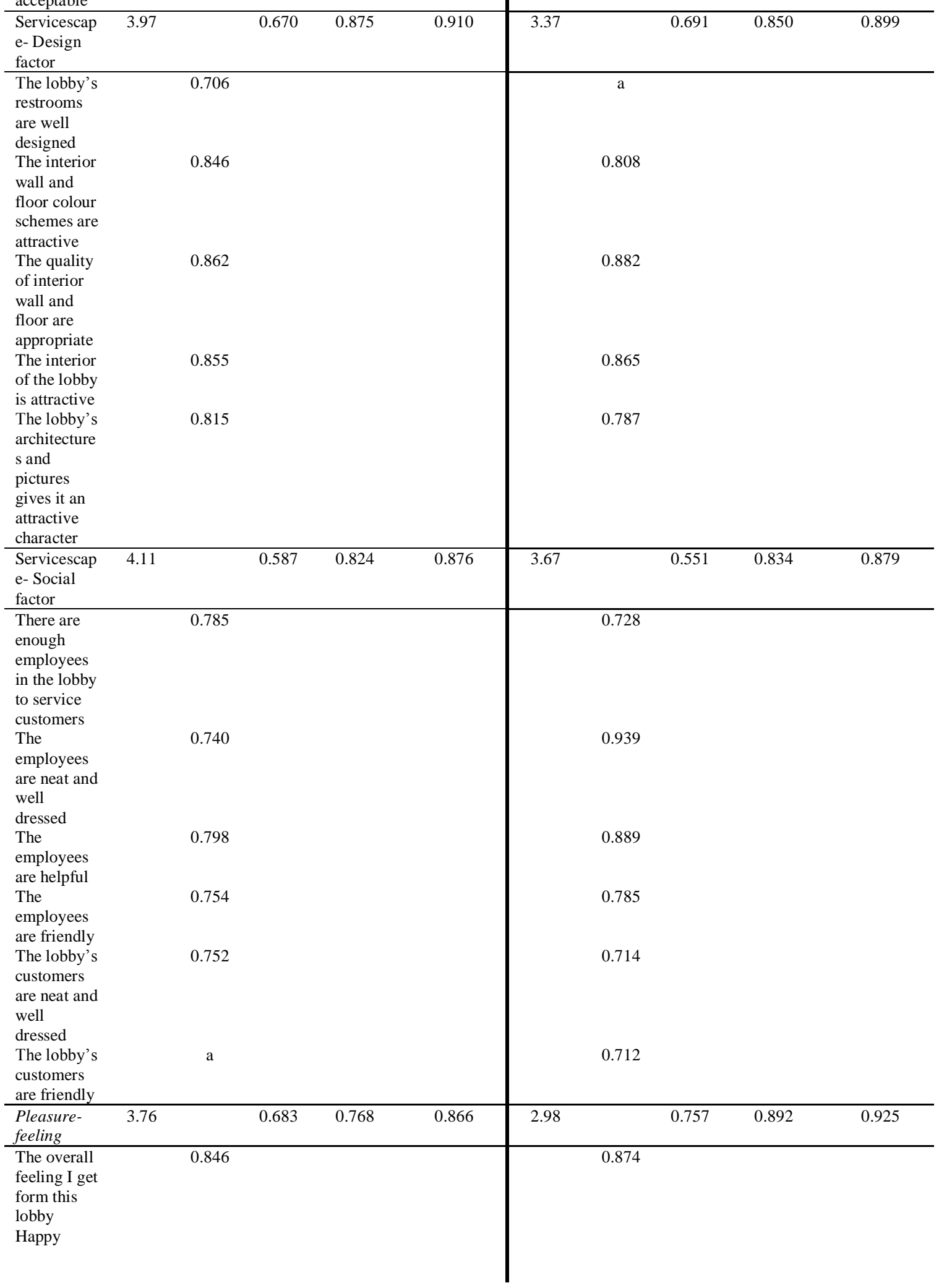

0.727

0.708

0.731 
Table 3: Measurement Results (cont'd)

The overall

0.831

feeling I get

form this

lobby

Delighted

The overall

feeling I get

form this

lobby

Pleased

The overall

feeling I get

form this

lobby

Entertained

Service

3.76

0.803

0.834

quality

quality of

this lobby is

excellent

The overall

quality of

this lobby is

much better

than I

expected

The overall

quality of

this lobby is

Just what it

should be

\begin{tabular}{|c|c|c|c|c|c|c|c|c|}
\hline Image & 4.06 & 0.755 & 0.892 & 0.925 & 3.71 & 0.759 & 0.893 & 0.926 \\
\hline $\begin{array}{l}\text { The overall } \\
\text { image of } \\
\text { hospital is } \\
\text { good }\end{array}$ & 0.866 & & & & 0.891 & & & \\
\hline $\begin{array}{l}\text { The image } \\
\text { of hospital } \\
\text { is clean }\end{array}$ & 0.864 & & & & 0.807 & & & \\
\hline $\begin{array}{l}\text { I feel } \\
\text { friendliness } \\
\text { about the } \\
\text { hospital }\end{array}$ & 0.871 & & & & 0.869 & & & \\
\hline $\begin{array}{l}\text { I like the } \\
\text { hospital in } \\
\text { overall }\end{array}$ & 0.874 & & & & 0.914 & & & \\
\hline
\end{tabular}

AVE - average variance extracted; a-item eliminated because factor loading (value lower than 0.707 ).

All Cronbach's alpha values are above 0.7 and all composite reliability values in Table 3 are above 0.8 . All constructs are reliable since the composite reliability values exceed the threshold value 0.7 .The measures demonstrate convergent validity as the average variance of manifest variables extracted by constructs (AVE) are above 0.5, indicating that more variance of each indicators are explained by their own construct. In order to analyse the discriminant validity, the square root of AVE should be greater than the correlation between the construct and other constructs in the model (Fornell and Larcker, 1981). Table 4 shows that this criterion has been met. 
Table 4: Discriminant Validity.

\begin{tabular}{ccccccc}
\hline Portugal & 1. & 2. & 3. & 4. & 5. & 6. \\
\hline AVE $^{1 / 2}$ & 0.869 & 0.827 & 0.744 & 0.819 & 0.829 & 0.766 \\
\hline 1.Image & 1.000 & & & & & \\
2. Pleasure-feeling & 0.619 & 1.000 & & & & \\
3.Ambient factor & 0.667 & 0.474 & 1.000 & & & \\
4.Design factor & 0.694 & 0.499 & 0.661 & 1.000 & & \\
5.S. Quality & 0.703 & 0.501 & 0.542 & 0.569 & 1.000 & \\
6.Social factor & 0.607 & 0.442 & 0.634 & 0.622 & 0.523 & 1.000 \\
\hline South Korea & 1. & 2. & 3. & 4. & 5. & 0.919 \\
\hline AVE & 0.871 & 0.870 & 0.741 & 0.831 & & \\
\hline 1.Image & 1.000 & & & & & \\
2. Pleasure-feeling & 0.498 & 1.000 & & & & \\
3.Ambient factor & 0.477 & 0.293 & 1.000 & & & \\
4.Design factor & 0.574 & 0.515 & 0.460 & 1.000 & & \\
5.S. Quality & 0.787 & 0.442 & 0.324 & 0.514 & 1.000 & \\
6.Social factor & 0.604 & 0.441 & 0.418 & 0.529 & 0.619 & 1.000 \\
\hline
\end{tabular}

Diagonal elements in the 'correlation of constructs' matrix are the square root of AVE. For adequate discriminant validity, diagonal elements should be greater than corresponding off-diagonal elements.

\section{Structural Results}

In this study a nonparametric approach, known as Bootstrap, was used to estimate the precision of the PLS estimates and supports the hypotheses (Chin, 1998; Fornell and Larcker, 1981). All path coefficients are found to be significant at the $0.001,0.01$ or 0.05 levels, and so all hypotheses are supported (see figure 2). However, as models yielding significant bootstrap statistics can still be invalid in a predictive sense (Chin et al., 2005), measures of predictive validity (such as $\left(\mathrm{R}^{2}\right.$ and $\mathrm{Q}^{2}$ ) for focal endogenous constructs should be employed. All values of $\mathrm{Q}^{2}$ (chi-squared of the Stone-Geisser Criterion) are positive, so the relations in the model have predictive relevance (Fornell and Cha, 1994). The model also demonstrated a good leve lof predictive power $\left(\mathrm{R}^{2}\right)$ as the modelled constructs explained $57.2 \%$ of the variance in image for Portugal and $48.6 \%$ for S. Korea; $51.5 \%$ in service quality for Portugal and $63.6 \%$ for S. Korea, $33.7 \%$ in pleasure-feeling for Portugal and $30.3 \%$ for S. Korea. In fact, the good value of GoF, proposed by Tenenhaus et al. (2005), and the good level of predictive power $\left(\mathrm{R}^{2}\right)$ reveal a good overall fit of the structural model (see Figure 2). The figures shown in the arrows linking each factor (first order constructs) of Servicescape and Servicescape itself (second order construct) are the weights. The statistical significance of those values means that the formative factors are significant.

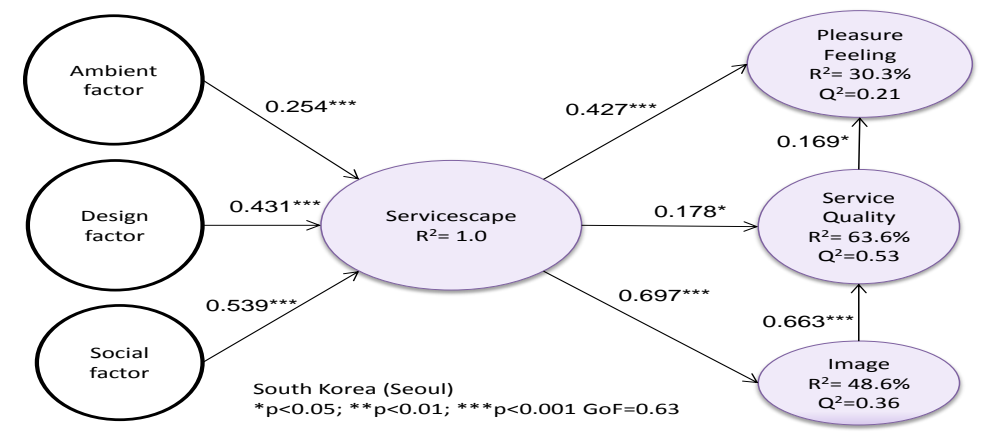

Figure 2: Structural Results 


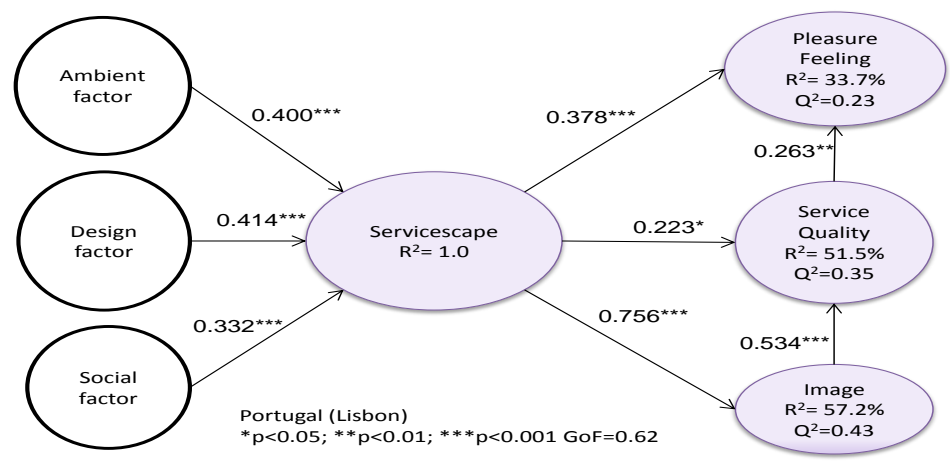

Figure 2: Structural Results (cont'd)

\section{Conclusions and Implications}

This study proposes a model that regards the effect of Servicescape on cognitive and affective outcomes into the context of health care hospital. The findings seem to show that a favourable Servicescape can lead to positive perceived service quality, a positive image of the hospital and a favourable pleasure-feeling in both counties. A good image perceived by customers can enhance perceived service quality and this, in turn, can enhance pleasure-feeling. However, the strength of the relationship between image and service quality appear to be higher than the strength of the relationship between service quality and pleasure-feeling. Moreover, the results for both countries seem to reveal that the direct interaction between Servicescape and service quality is weaker than the direct interaction between Servicescape and image or Servicescape and pleasure-feeling.The findings do not corroborate previous studies in sport (Baseball) (Hightower et al., 2002) context. The reason seems to be the nature of healthcare hospital context, that is, patients tend to associate the concept of service quality more to medical treatment than to lobby characteristics and so Servicescape is more related to image and pleasure-feeling.

All three factors of Servicescape are found to be significant in the formation of Servicescape itself. However, ambient and design factors seem to be more important factors than social factor in Portuguese context in building Servicescape perception. In the case of S. Korean context social and design factors seem to be more important factors than ambient factor in building Servicescape perception. The findings seem to reveal that in Portugal should be given more attention to the ambient (lights, odour and noise) and lobby's architectures and decoration. In the S. Korea context, it seems to be importantgo further in. building empathy with patients and their family when they arrive at the lobby and integrate that personal empathy with the layout of the lobby in order to welcome patients and family.

The findings are in accordance with those of Kim and Moon (2009) for restaurant context or Loureiro and Miranda (2008) for rural tourism context. In fact, Servicscape is an important determinant of service quality, image and pleasure-feeling. Nevertheless, the values of the paths seem to reveal that in case of health care hospital in Portugal, Servicescape is especially important to predict the customer evaluation of the image of the hospital and the pleasure-feeling. In this vein, the way hospital lobby is organized, the layout, the equipment, the signage, and all ambient elements should not be overlooked because it is the first impression to attract customers. Once again 
the S-O-R model (since our model is an extension of S-O-R) proved be appropriate in explaining the effect of stimuli on emotions, such as pleasure feeling. However, stimuli, or better, the Servicescape has an important effect in more cognitive variables, such as service quality.

Regarding implications for the managers, they should take more attention to the social components of Servicespace, that is, the number of employees in the lobby, their empathy and the way are dressed. More attention to the employees may enhance the overview of the Servicescape. The customer perception that they are always been helped and supported may improve the perception of service quality and this together with a favourable image may lead to a better pleasure-feeling. This consideration seems to be more crucial in Seoul hospital lobby than in Lisbon hospital lobby. Technologically advanced equipment and modern facilities are very important to achieve good treatments and givea good perceived image. Nevertheless, the human factor should not be neglected, not only the technical skill, but also the ability to establish a good relationship with each patient. Once all hospitals have high service quality standards, the environment, the architecture and the social component emerge as the key factors in providing a pleasure-feeling to patients and family while waiting.

In the future other health care medical tourism hospitals should be analysed and compared in order to better understand the phenomenon. In this first study we capture mainly medical inboard tourists in each countries (coming from other regions in the same country). Therefore, in order to properly generalize the findings, in future we intend to extend the period to gather data, translate and back translate the questionnaire to other languages and capture the perception of medical tourists all over a year. Nation cultures could be a moderator variable to be consider. Other variables may be integrated in the model, such as behavioural intentions, trust and attachment to the hospital. How tourists identified themselves with the hospital? Finally, it will be also interesting to compare the perceptions of younger medical tourists with older medical tourists.

\section{References}

Baker, J., Levy, M., and Grewal, D. (1992). "An Experimental Approach to Making Retail Store Environmental Decisions". Journal of Retailing, 68: 445-460.

Bitner, M. J. (1992). "Servicescape: the impact of the physical environment surrounds customers and employees". Journal of Marketing 256: 69- 82.

Booms, B.H, and Bitner, M J. (1981). Marketing strategies and organization structure for service firms. In Donnelly, J. and George, (Eds), Marketing of Services, Chicago: American Marketing: 47-51.

Brislin, R. W. (1970). "Back-translation for cross-cultural research". Journal of CrossCultural Psychology 1(3): 185-216.

Carrera, P., and Bridges, J. F. P. (2006). "Globalization and healthcare: understanding health and medical tourism". Expert Review of Pharmacoeconomics and Outcomes Research, 6(4), 447-454.

Chin, W. W. (1998). The partial least squares approach to structural equation modeling. In G. A. Marcoulides (ed.), Modern Methods for Business, Mahwah, NJ; Lawrence Erlbaum Associates Publisher: Mahwah: 295-336.

Chin, W. W., Marcolin, B. L., And Newsted, P. R. (2003). "A partial least squares latent variable modeling approach for measuring interaction effects: results from a monte carlo simulation study and an electronic mail adoption study". Information systems research,14: 189-217. 
Crooks, V. A., Kingsbury, P., Snyder, J., and Johnston, R. (2010). "What is known about the patient's experience of medical tourism? A scoping review". BMC Health Services Research,10: 266-278.

Donovan, R. J., and Rossiter, J. R. (1982). "Store Atmosphere: An Environmental Psychology Approach”. Journal of Retailing,_58: 34-57.

Ehrbeck, T., Guevara, C., and Mango, P. D. (2008). "Mapping the market for medical tourism". McKinsey Quarterly_May, 1-11.

Eroglu, S. A., Machleit, K. A., and Davis, L. M. (2001). "Atmospheric Qualities of Online Retailing a Conceptual Model and Implications". Journal of Business Research, 54: 177-184.

Fedorov, G., Tata, S., Raveslooy, B., Dhakal, G., Kanosue, Y., and Roncarati, M. (2009). Medical Travel in Asia and the Pacific: challenges and opportunities. Bangkok: UN Economic and Social Commission for Asia and the Pacific.

Fornell C., and Larcker, D. F. (1981). "Evaluating structural models with unobservable variables and measurement error". Journal of Marketing Research, 18(1): 39-50.

Gesler, W. (1992). "Therapeutic landscapes: Medical issues in light of the new cultural Geography". Social Science Medicine, 34: 735-746.

Goodrich, J. N. (1993). "Socialist Cuba: A Study of Health Tourism". Journal of Travel Research,32(1): 36-41.

Gröonros, C. (1990). Service management and marketing: Managing the moments of truth in service competition. Lexington, MA: Lexington Books and Macmillan, Inc.

Hall, C. (2011). "Health and medical tourism: a kill or cure for global public health?" Tourism Review 66(1/2): 4-15.

Hazarika, I. (2010). "Medical tourism: its potential impact on the health workforce and health systems in India". Health Policy and Planning,25: 248-251.

Heung, V., Kucukusta, D., and Song, H. (2010). "A Conceptual Model of Medical Tourism: Implications for Future Research", Journal of Travel and Tourism Marketing, 27: 236-251.

Hightower, R., Brady, M., and Baker, T. (2002). "Investigating the role of the physical environment in hedonic service consumption: an exploratory study of sporting events". Journal of Retailing $\mathbf{2 5 5}(9)$ : 697-707.

Huat, J. Y. C. (2006a). "Medical Tourism/Medical Travel (part one)". SMA News_38: 17-21.

Huat, J. Y. C. (2006b). "Medical Tourism/Medical Travel (part two)". SMA News 38: 14-16.

IMTJ (2014). Retrieved on 1 of December 2014 from http://www.imtj.com/news/?entryid82=442510.

Jeon, J. H. (2011). "The Effect of Corporate Social Responsibility on the Corporate Image and Purchase Intention". Journal of the Korean Society of Clothing and Textiles35(5): 547-560.

Johnson, T., and Garman, A. (2010). "Impact of medical travel on imports and exports of medical services". Health Policy,98: 171-177.

Kim, W.G. and Moon, Y.J. (2009). "Customers' cognitive, emotional, and actionable response to the servicescape: A test of the moderating effect of the restaurant type". International Journal of Hospitality Management,_28(1): 144-156.

Kleijnen, M., Ruyter, K., and Wetzels, M. (2007). "An assessment of value creation in mobile service delivery and the moderating role of time consciousness". Journal of Retailing,83(1): 33-46.

Koo, D. M., and Ju, S.H. (2010). "The interactional effects of atmospherics and perceptual curiosity on emotions and online shopping intention". Computers in Human Behavio,r 26: 377-388.

Lazarus, R. (1991). Emotion and Adaptation. Oxford: Oxford University Press.

Lee, C. (2010). "Health care and tourism: Evidence from Singapore". Tourism Management, 31: 486-488.

Lee, L., Buse, K., and Fustukian, S. (Eds.). (2002). Health Policy in a Globalising World. Cambridge: Cambridge University Press. 
Loureiro, S. M. C., and Miranda G., F. J. (2008). "The importance of quality, satisfaction, trust and image in relation to rural tourism loyalty". Journal of Travel and Tourism Marketing,25(2): 117-136.

Loureiro, S. M. C., Koo, D.-M., and Ribeiro, L. (2013). "Effects of Atmospherics on Emotions and Intention with Respect to Involvement under Different Shopping Environments". Journal of Global Scholars of Marketing Science(Bridging Asia and the World),23(4): 435-459.

Lucas, A.F. (2003). "The determinants and effects of slot servicescape satisfaction in a Las Vegas hotel casino". UNLV Gaming Research and Review Journal,7(1): 1-17.

Lunt, N., Hardey, M., and Mannion, R. (2010). "Nip, tuck and click: medical tourism and the emergence of web-based health information". Open Medical Informatics Journa,l 4: $1-11$.

Lunt, N., Exworthy, M., Green, S., Horsfall, D., Mannion, R., and Smith, R. (2011). Medical Tourism: Treatments, Markets and Health System Implications: A Scoping Review. Paris: Organisation for Economic Co-operation and Development.

McKinney, L. N. (2004). "Creating a Satisfying Internet Shopping Experience Via Atmospherics Variables".International Journal of Consumer Studies,28: 268-283.

Medicaltourismmagazine (2014). "Portugal preparing for medical tourism". Retrieved on 1 of May 2014 from http://www.medicaltourismmag.com/portugal-preparing-medicaltourism/.

Medicaltourismmagazine-Jesu (2014). "Jeju: Hidden Gem more than Island resort”. Retrieved on 1 of May 2014 from http://www.medicaltourismmag.com/jeju-hidden-gem-islandresort/.

Mehrabian, A., and Russell, J. A. (1974). An approach to environmental psychology. Cambrige, MA: MIT Press.

Michaelia C. K. Y. (2008). The Role of Servicescape in convention and exhibition Centre and AsiaWorld-Expo. Unpublished bachelor thesis. Hong Kong: Hong Kong Baptist University, Marketing.

NaRanong, A., and NaRanong, V. (2011). "The effects of medical tourism: Thailand's experience". Bulletin of the World Health Organization89(5): 336-4.

Rapoport, A. (1982). The Meaning of the Built Environment. Beverly Hills, CA: Sage Publications, Inc.

Ryu, K. and Jang, S. (2007). "The effect of environmental perceptions on behavioral intentions through emotions: the case of upscale restaurants". Journal of Hospitality and Tourism Research,31(1): 56-72.

Sherman, E., Mathur, A., and Smith, R. B. (1997). "Store Environment and Consumer Purchase Behavior: Mediating Role of Consumer Emotions". Psychology and Marketing14: 361-378.

Smith, M., and Puczkó, L. (Eds.). (2008). Health and Wellness Tourism. Oxford: Butterworth-Heinemann/Elsevier.

Tenenhaus, M., Vinzi, V. E., Chatelin, Y.-M., and Lauro, C. (2005). "PLS Path Modeling". Computational Statistics and Data Analysis 48: 159-205.

Thang, D. C., and Tan, B. L. (2003). "Linking Consumer Perception to Preference of Retail Stores: An Empirical Assessment of Multiple-Attributes of Store Image". Journal of Retailing and Consumer Service 10: 193-200.

Turley, L.W., and Fugate, D.L. (1992). "The multidimensional nature of service facilities: viewpoints and recommendations". The Journal of Services Marketing, 6(3): 37-53.

Wakefield, K. L., and Blodgett, J. G. (1994). "The Importance of Servicescapes in Leisure Service Settings”. Journal of Services Marketing_8: 66-76.

Wakefield, K.L., and Blodgett, J.G. (1999). "Customer response to intangible and tangible service factors". Psychology and Marketing 16(1): 51-68.

Wetzels, M., Odekerken-Schröder, G., and van Oppen, C. (2009). "Using PLS path modeling for assessing hierarchical construct models: Guidelines and empirical illustration". MIS Quarterly,33: 177-195. 
Whittaker, A., Manderson, L., and Cartwright, E. (2010). "Patients without borders: understanding medical travel”. Medical Anthropology,29(4):336-343.

WHO (2014). World health organization assesses the world's health systems. Retrieved on 2 of December 2014 fromwww.photius.com/rankings/who_world_health_ranks.html 